\title{
6 The economic and carbon impact of China's outward foreign direct investment in the power sector
}

\author{
Hikari Ban and Kiyoshi Fujikawa
}

\section{Introduction}

In 2013, China's outward foreign direct investment (OFDI) totaled US\$ 73 billion. However, after the 2013 announcement of the "One Belt and One Road Initiative," it rapidly increased, reaching US\$ 216 billion in 2016, making China the second-largest international investor worldwide after the United States of America (USA). ${ }^{1}$ Since then, it has declined slightly. Nonetheless, China remains a major global player in OFDI.

In terms of the power sector, the capacity of the power plants that China committed as OFDI in 2013 totaled 6,376 megawatts (MW), ${ }^{2}$ which tripled to $18,761 \mathrm{MW}$ in 2017. According to an estimate by Li et al. (2020), Chinese power companies' overall OFDI between 2000 and 2017 reached nearly US\$ 115 billion.

One reason for Chinese OFDI in the power sector is that it mitigates air pollution and promotes China's National Determined Contribution to the Paris Agreement and the achievement of carbon neutrality by 2060 .

In this chapter, we examine the economic and environmental effects of Chinese OFDI in power sector to other Asian countries and regions since 2014 using China's Global Power Database developed by Boston University (Gallagher et al., 2019). In other words, we determine how China's carbon relocation policy may affect the international economy and global environment.

To quantitatively evaluate these effects, we use a computable general equilibrium (CGE) model. CGE models incorporate the optimization behaviors of each economic agent under budget constraints and determine the output and prices required to clear goods and factor markets. CGE analysis is a suitable tool for investigating the wide-ranging impact of foreign direct investment (FDI) on both input and final goods markets and enables us to examine the environmental impact of FDI by assessing the resultant changes in output, prices, trade, and the energy mix of all industries as well as electricity production.

This chapter has novelty in analytical methodology and empirical evidence. For the analytical methodology, the chapter uses the actual amount 
of FDI in coal power to run a CGE model, which has been mostly applied to estimate the impacts of free trade agreements. For the empirical evidence, it quantitatively shows carbon leakage accompanied by the past Chinese FDI in power sector in Asian countries.

\section{Model and data}

\subsection{Model}

Despite its suitability as a tool for assessing FDI, fewer studies on FDI using a CGE model exist than studies on free trade agreements, perhaps owing to the lack of available FDI data. Moreover, it seems that even less relevant research on FDI's environmental impact appears in the extant literature. ${ }^{3}$

A conventional means for incorporating FDI into the CGE model is to treat FDI as a change in capital stock. Brown, Deardorff, and Stern (1992) examined the economic effects of increasing Mexican capital stock using FDI from outside of the North American Free Trade Agreement. Ban et al. (1998) determined the economic influence of Japanese FDI on nine Asian countries. Fujikawa and Ban (2016) also investigated the economic and environmental impact of FDI from Japan on Association for South East Asian Nations (ASEAN) countries.

In contrast, this chapter analyzes the economic and environmental effects of FDI specific to the power sector by modifying the Energy-Environmental Version of the Global Trade Analysis Project (GTAP-E) model that considers the links between the economy, the energy sector, and the environment (i.e., as represented by carbon dioxide $\left[\mathrm{CO}_{2}\right]$ emissions) to accommodate direct investment by industry. ${ }^{4}$ The meaning of the specified factor in this model is explained briefly below.

The GTAP standard model, which is a static model, includes capital, unskilled labor, skilled labor, land, and natural resources as production factors, each of which is constant and does not move internationally at the initially given amount. Because the savings earned during the period are invested in each country according to an expected rate of return on capital, the amount of capital at the end of the period differs from the amount at the beginning. The production factors can be moved between domestic industries. They are classified into three distinct factors: mobile factors, sluggish factors, and specified/fixed factors.

A mobile factor can move freely among domestic industries. There is only one labor market in each country wherein the wage rate fluctuates such that the total demand for labor is equal to the total supply of labor, which is given as an exogenous variable.

Moving a sluggish factor to another industry is difficult, and its supply to an individual industry is less than perfectly elastic. An example of a sluggish factor is land. The total amount of land in a country is an exogenous variable. The supply of land to an individual industry is determined by the total amount of land and the industry-specific returns on the land through 
a transformation function. ${ }^{5}$ If the overall land supply increases or industryspecific returns on land rise, the amount of land allocated to that industry increases. Industry-specific returns on land are determined to balance the supply and demand in each industry's land market.

A specified factor cannot move between industries. If capital is a specified factor, the amount of capital used by industry is treated as an exogenous variable, and there is a capital market by industry. Industry-specific returns on capital are determined such that the supply and demand of each market are balanced. In this study, we modified the GTAP-E model so that capital, land, and natural resources could be treated as specified factors.

Figure 6.1 illustrates the GTAP-E's production function, which has a Leontief structure with zero elasticity of substitution at the top level and a constant elasticity of substitution (CES) structure at the lower level. The Leontief structure implies that the inputs will be used in fixed proportion and the CES structure allows for constant substitutability between the inputs.

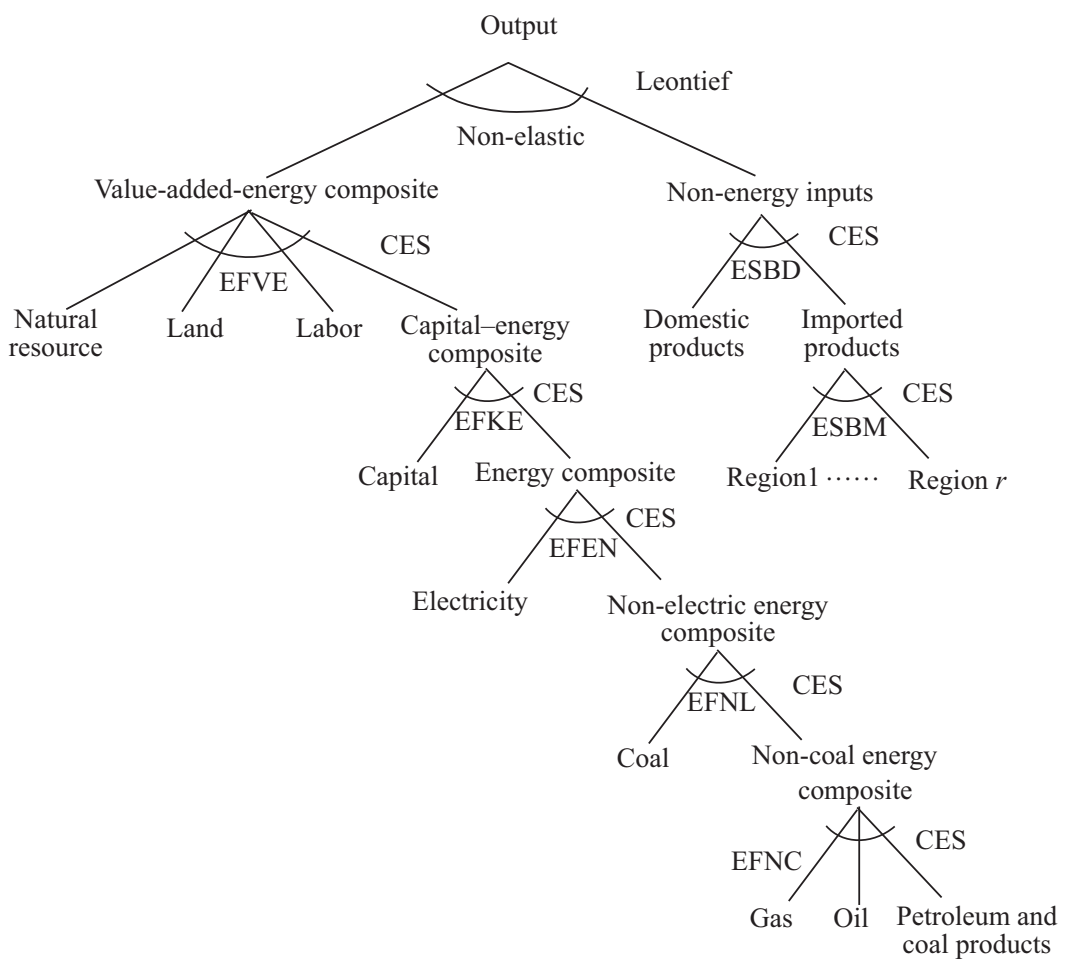

Figure 6.1 Production function of the GTAP-E model.

Source: The authors modified a figure that appeared in Burniaux and Truong (2002). 
This production function is structured to enable substitution between capital and energy and substitution between different energy sources. The energy composite is combined with capital and incorporated into the valueadded nest to consider energy-capital adjustment to a relative price change. Energy commodities are incorporated into the energy composite at three levels of nested substitution.

The model employs the Armington approach in that firms first determine the source of their imports and then compare the prices of domestic goods and the optimal mix of imports. ${ }^{6}$

\subsection{Data}

This model uses the GTAP 10A Data Base (Aguiar et al., 2019), which corresponds to the global economy of 2014 with 141 countries/regions and 65 sectors. The production factors include land, natural resources, capital, unskilled labor, and skilled labor. Land, natural resources, and capital are

Table 6.1 Regional classifications

\begin{tabular}{|c|c|c|}
\hline No. & Country/Region & $\begin{array}{l}\text { Abbreviation } \\
\text { in this chapter }\end{array}$ \\
\hline 1 & Oceania & Oce \\
\hline 2 & China & Chn \\
\hline 3 & Japan & Jpn \\
\hline 4 & Korea & Kor \\
\hline 5 & Mongolia & Mng \\
\hline 6 & Taiwan & \\
\hline 7 & Other East Asia & \\
\hline 8 & Indonesia & Idn \\
\hline 9 & Malaysia & \\
\hline 10 & Singapore & \\
\hline 11 & Thailand & \\
\hline 12 & Vietnam & Vnm \\
\hline 13 & Rest of ASEAN & \\
\hline 14 & India & Ind \\
\hline 15 & Other South Asia & \\
\hline 16 & Canada & \\
\hline 17 & USA & \\
\hline 18 & Latin America & \\
\hline 19 & $\begin{array}{l}\text { European Union (EU) and European Free Trade } \\
\text { Association (EFTA) }\end{array}$ & EUEFTA \\
\hline 20 & Rest of Europe & \\
\hline 21 & Russia & Rus \\
\hline 22 & Turkestan & Trk \\
\hline 23 & Middle East and North Africa & \\
\hline 24 & Sub-Saharan Africa & \\
\hline
\end{tabular}

Source: The authors' compilation based on the GTAP 10A Data Base. 
Table 6.2 Industrial sector classifications

\begin{tabular}{|c|c|c|}
\hline No. & Industrial sector & Abbreviation in this chapter \\
\hline 1 & Agriculture & \\
\hline 2 & Livestock & \\
\hline 3 & Forestry & \\
\hline 4 & Fishing & \\
\hline 5 & Coal mining & Coal \\
\hline 6 & Crude oil & \\
\hline 7 & Gas and distribution & \\
\hline 8 & Petroleum and coal products & P_C \\
\hline 9 & Electricity & Ely \\
\hline 10 & Other mining & Min \\
\hline 11 & Processed food & \\
\hline 12 & Textiles and cloth & \\
\hline 13 & Paper products and publishing & PPP \\
\hline 14 & Chemical products & Chm \\
\hline 15 & Non-metallic mineral products & NMM \\
\hline 16 & Iron and steel & I_S \\
\hline 17 & Automobile & \\
\hline 18 & Transport equipment & \\
\hline 19 & Electronic equipment & \\
\hline 20 & Machine equipment & \\
\hline 21 & Other manufactures & \\
\hline 22 & Water & \\
\hline 23 & Construction & \\
\hline 24 & Trade & \\
\hline 25 & Water transport & Wtp \\
\hline 26 & Air transport & Atp \\
\hline 27 & Other transport & Otp \\
\hline 28 & Services & Sve \\
\hline
\end{tabular}

Source: The authors' compilation based on the GTAP 10A Data Base.

assumed to be specified elements that do not move between industries. Only unskilled and skilled labor can move between industries.

The geographic locations were organized into 24 regions located primarily in Asia, as listed in Table 6.1. Here, Turkestan comprises Kazakhstan, Kyrgyzstan, Tajikistan, Turkmenistan, and Uzbekistan, even though Turkmenistan and Uzbekistan are integrated into the GTAP Data Base.

Energy-related and energy-intensive industries were classified into $28 \mathrm{sec}-$ tors, as listed in Table 6.2.

Table 6.3 exhibits the values for the elasticities of substitution. EFVE to EFNC represent the elasticity of substitution of the composites illustrated in Figure 6.1. ESBD and ESBM represent the Armington parameters for domestic or imported allocation and regional allocation of imports, respectively. The values for the elasticities of substitution, except for EFVE, are common to all countries. 
Table 6.3 Elasticity of substitution in the value-added and energy composites

\begin{tabular}{|c|c|c|}
\hline Notation & Composite & Elasticity of substitution \\
\hline EFVE & $\begin{array}{l}\text { Between value-added } \\
\text { components }\end{array}$ & $\begin{array}{l}\text { Common for all countries/regions except for } \\
\text { sectors such as Coal, Oil, Gas, and Svc }\end{array}$ \\
\hline EFKE & $\begin{array}{l}\text { Between capital and } \\
\text { energy composite }\end{array}$ & Coal, Oil, Gas, P_C: 0; Other industries: 0.5 \\
\hline EFEN & $\begin{array}{l}\text { Between energy } \\
\text { components }\end{array}$ & $\begin{array}{l}\text { Coal, Oil, Gas, P_C, Ely: 0; Other } \\
\text { industries: } 1\end{array}$ \\
\hline EFNL & $\begin{array}{l}\text { Between non-electrical } \\
\text { energies }\end{array}$ & Coal, Oil, Gas, P_C: 0; Other industries: 0.5 \\
\hline EFNC & $\begin{array}{l}\text { Between non-coal } \\
\text { energies }\end{array}$ & Coal, Oil, Gas, P_C: 0; Other industries: 1 \\
\hline ESBD & $\begin{array}{l}\text { Between domestic and } \\
\text { imported products }\end{array}$ & 0.90 (Min)-12.97 (Gas) \\
\hline ESBM & $\begin{array}{l}\text { Between origins of } \\
\text { import }\end{array}$ & 1.80 (Min)-32.39 (Gas) \\
\hline
\end{tabular}

Source: The authors' compilation based on the GTAP 10A Data Base.

\section{Simulation scenarios}

Table 6.4 displays the power generation capacity of FDI generated by electricity from China by power source. We have picked up the data only after 2014 , and this data includes those in operation and under construction. The top 10 countries in terms of power generation capacity for FDI generated by electricity from China are as follows: Pakistan, Vietnam, Indonesia, Malaysia, India, Bangladesh, Laos, Australia, Cambodia, and Turkestan.

However, power source composition varies greatly from country to country. Pakistan accepts FDI into various energy sources such as natural gasfired power, hydropower, nuclear power, solar power, and wind power in addition to coal-fired power. In Malaysia and Bangladesh, FDI in natural gas-fired power and coal-fired power are substantial. Wind power in Australia and hydropower in Laos and Cambodia account for the majority of the two countries' respective FDI inflows.

Since this chapter considers the impact of FDI in coal-fired power generation from China, we will also cover four other countries/regions: Vietnam, Indonesia, India, and Turkestan.

To conduct a scenario analysis using the GTAP-E model, it is necessary to estimate the amounts of FDI flows from China in US\$. This study uses overnight costs for coal plants in China-US\$ 813 per kilowatt $(\mathrm{kW})$-as estimated by International Energy Agency (IEA)/Nuclear Energy Agency (NEA) (2015). ${ }^{7}$ Our calculations indicate that China has invested US\$ 6.42 billion in Indonesia, US\$ 8.96 billion in Vietnam, US\$ 3.06 billion in India, and US\$ 0.69 billion in Turkestan since 2014 for a total of US\$ 19.12 billion.

To investigate the impact of these FDI flows from China, the first stage of this analysis sets scenarios in which the capital stock in the donor country decreases according to conventionally applied scenarios in models with exogenous capital shock. Tables $6.5 \mathrm{a}$ and $6.5 \mathrm{~b}$ summarize the shock values given 
Table 6.4 Power generation capacity of FDI from China by power source (in MW)

\begin{tabular}{lrrrrrrrr}
\hline & Coal & Gas & Hydro & Nuclear & Oil & Solar & Wind & Total \\
\hline Pakistan & 4,950 & 1,999 & 1,688 & 2,880 & 215 & 500 & 297 & 12,530 \\
Vietnam & 11,016 & 0 & 0 & 0 & 0 & 0 & 0 & 11,016 \\
Indonesia & 7,895 & 0 & 110 & 0 & 0 & 0 & 0 & 8,005 \\
Malaysia & 1,505 & 4,540 & 0 & 0 & 0 & 50 & 0 & 6,095 \\
India & 3,760 & 0 & 0 & 0 & 0 & 0 & 0 & 3,760 \\
Bangladesh & 1,320 & 1,088 & 0 & 0 & 256 & 0 & 0 & 2,664 \\
Laos & 0 & 0 & 2,018 & 0 & 0 & 0 & 0 & 2,018 \\
Australia & 0 & 126 & 30 & 0 & 0 & 160 & 1,500 & 1,816 \\
Cambodia & 405 & 0 & 984 & 0 & 0 & 0 & 0 & 1,389 \\
Turkestan & 850 & 0 & 0 & 0 & 0 & 0 & 0 & 850 \\
\hline
\end{tabular}

Note: The value for Turkestan is equal to the sum of Kyrgyzstan, Tajikistan, and Uzbekistan as there was no FDI from China into coal-fired power generation in Kazakhstan during the applicable period.

Source: The authors' compilation based on Gallagher et al. (2019).

Table 6.5a Scenarios simulated for FDI analysis

\begin{tabular}{|c|c|}
\hline Scenario name & Power sector capital change shock \\
\hline $01 E-c h n$ & Capital decrease in China only \\
\hline $02 E-i d n$ & Capital increase in Indonesia only \\
\hline $03 E-v n m$ & Capital increase in Vietnam only \\
\hline $04 E$-ind & Capital increase in India only \\
\hline 05E-trk & Capital increase in Turkestan only \\
\hline 06E-chnidn & Capital transfer from China to Indonesia \\
\hline 07E-chnvnm & Capital transfer from China to Vietnam \\
\hline 08E-chnind & Capital transfer from China to India \\
\hline 09E-chntrk & Capital transfer from China to Turkestan \\
\hline $10 E$-ivit & Capital increase in Indonesia, Vietnam, India, and Turkestan \\
\hline 11E-chnivit & $\begin{array}{l}\text { Capital transfer from China to Indonesia, Vietnam, India, and } \\
\text { Turkestan }\end{array}$ \\
\hline
\end{tabular}

Table 6.5b Capital change shock of each scenario (\%)

\begin{tabular}{|c|c|c|c|c|c|}
\hline & China & Indonesia & Vietnam & India & Turkestan \\
\hline $01 E-c h n$ & -1.91 & & & & \\
\hline $02 E-i d n$ & & 49.19 & & & \\
\hline $03 E-v n m$ & & & 46.57 & & \\
\hline $04 E$-ind & & & & 2.96 & \\
\hline $05 E$-trk & & & & & 4.09 \\
\hline $06 E-c h n i d n$ & -0.64 & 49.19 & & & \\
\hline 07E-chnvnm & -0.89 & & 46.57 & & \\
\hline 08E-chnind & -0.31 & & & 2.96 & \\
\hline 09E-chntrk & -0.07 & & & & 4.09 \\
\hline $10 E$-ivit & & 49.19 & 46.57 & 2.96 & 4.09 \\
\hline 11E-chnivit & -1.19 & 49.19 & 46.57 & 2.96 & 4.09 \\
\hline
\end{tabular}

Source: The authors' compilation based on the GTAP 10A Data Base. 
to the initial power capital for each scenario. The scenarios from $01 E$-chn to $05 E$-trk are those wherein the capital change shock is given for only one country or region. In the $01 E$-chn scenario, China's electricity capital decreases by US $\$ 19.12$ billion. In the scenarios between $02 E$-idn and $05 E$-trk, Indonesia, Vietnam, India, and Turkestan's electricity capital increases by US\$ 6.42 billion, US\$ 8.96 billion, US\$ 3.06 billion, and US\$ 0.69 billion, respectively. The scenarios from $06 E$-chnidn to $09 E$-chntrk are those in which power capital transfers bilaterally. The shocks to China's electricity capital in these scenarios correspond to the capital increase of each host country. The $10 E$-ivit scenario is a scenario in which China's electricity capital does not change and instead overseas electricity capital increases. In the 11E-chnivit scenario, China's electricity capital is reduced by US\$ 19.12 billion, and FDI recipients' electricity capital increases by the above amount.

\section{Simulation results}

\subsection{Impact on power sector}

Naturally, by industry, the electrical power sector with the largest changes in capital is the most affected. The effects on output and prices are reported in Table 6.6. Electricity production declines and prices rise in China, and vice versa in capital-receiving countries.

\subsection{Impact on gross domestic product (GDP)}

Table 6.7 shows how changes in power sector capital impact the GDP of each country or region. GDP decreases in China when the power capital decreases, while it increases in host countries in which the power capital increases. Although the amount of power capital does not change, the decrease in Mongolia's GDP under the 01E-chn,07E_chnvnm, and 11E-chnivit scenarios is relatively noticeable. In the countries/regions that are not listed in Table 6.7, GDP hardly changes.

\subsubsection{The 01E-chn scenario}

In Tables $6.5 \mathrm{~b}$ and 6.7, we can see that in the $01 E$-chn scenario, a $1.91 \%$ reduction in electricity capital will reduce China's GDP by $0.02 \%$. From Table 6.6, production in China's power sector will fall by $0.55 \%$, and its price will rise by $0.82 \%$. A decrease in electricity production will reduce coal demand, causing China's coal production to decrease by $0.06 \%$. Furthermore, the rise in electricity prices will negatively impact production in most Chinese industries. All of these effects ultimately lead to a decline in China's GDP.

Outside China, the impact on Mongolia's GDP seems relatively large. This is attributable to trade in coal and electricity. The decline in Chinese coal demand will negatively influence coal production in regions other than China. For example, Oceania, Indonesia, and Mongolia's coal exports to China will decrease by $0.10 \%, 0.10 \%$, and $0.02 \%$, respectively, and production will 
Table 6.8 Share of value-added to GDP (\%)

\begin{tabular}{|c|c|c|c|c|c|c|}
\hline & Oce & Chn & Jpn & Kor & Mng & $I d n$ \\
\hline Coal sector & 2.15 & 1.20 & 0.00 & 0.01 & 10.79 & 4.32 \\
\hline \multirow[t]{2}{*}{ Electricity sector } & 1.36 & 1.79 & 0.98 & 1.69 & 8.06 & 0.31 \\
\hline & Vnm & Ind & $U S A$ & EUEFTA & Rus & Trk \\
\hline Coal sector & 1.22 & 1.43 & 0.21 & 0.08 & 0.80 & 1.39 \\
\hline Electricity sector & 2.97 & 4.46 & 1.15 & 1.41 & 1.66 & 2.53 \\
\hline
\end{tabular}

Source: The authors' compilation based on the GTAP 10A Data Base.

also decrease slightly. ${ }^{8}$ Because the value-added of Mongolia's coal industry accounts for a relatively high proportion of its GDP, this shock may lead to a decrease in its overall GDP (see Table 6.8).

The rise in electricity prices in China will affect the trade in electricity. In Mongolia, the electricity consumption of industry and households is 1.57 million tons of oil equivalent (Mtoe), of which imported electricity comprises 0.11 Mtoe or $7.21 \%$. Since $51.25 \%$ of imported electricity comes from China, the negative effect of rising imported electricity prices on the Mongolian economy is relatively large.

\subsubsection{The 02E-idn, 03E-vnm, 04E-ind, and 05E-trk scenarios}

GDP increases in capital-receiving countries but not necessarily in proportion to the rate of increase in electricity capital. Comparing the $02 E$-idn and $03 E$-vnm scenarios, the rate of increase in electricity capital in Indonesia is slightly higher than in Vietnam. However, Indonesia's GDP growth rate in the $02 E$-idn scenario seems to be considerably smaller than that of Vietnam's GDP growth rate in the $03 E$-vmn scenario. As shown in Table 6.6, the power sector's output will increase by $6.40 \%$ in Indonesia and by $12.71 \%$ in Vietnam. Electricity prices decrease by $-7.76 \%$ in Indonesia and by $-12.70 \%$ in Vietnam. In addition, Vietnam trades power internationally, so its exports will increase by $113.28 \%$ in the $03 E$ - $v n m$ scenario.

One reason for the different responses from these two countries is the capital-labor ratio in the electrical power sector: Indonesia's is 4.23 and Vietnam's is 1.10 . Vietnam's electricity sector, wherein capital is a scarce factor, will be able to more efficiently replace labor with cheaper capital, which will lower electricity prices. The rate of change in demand for unskilled and skilled labor in the electrical power sector is $-4.52 \%$ and $-4.54 \%$ in Indonesia and $-7.91 \%$ and $-7.77 \%$ in Vietnam, respectively.

If the cost of electricity accounts for a large proportion of the total cost, the benefits of lower electricity prices will become greater. Table 6.9 shows the share of electricity costs and the rates of change in prices, production, and exports in the energy-intensive goods sector. Vietnam's energy-intensive goods industry, which bears a higher electricity cost share than Indonesia, exhibits a more substantial rate of price decline and increased production and exports. 
Table 6.9 Electricity cost shares and responses in energy-intensive industries (\%)

\begin{tabular}{|c|c|c|c|c|}
\hline & $P P P$ & Che & $N M M$ & $I \_S$ \\
\hline \multicolumn{5}{|c|}{ Initial share of electricity costs in total costs } \\
\hline Indonesia & 1.15 & 0.83 & 1.45 & 5.28 \\
\hline Vietnam & 10.78 & 3.04 & 9.02 & 18.25 \\
\hline \multicolumn{5}{|c|}{ Change rate in product price } \\
\hline Indonesia & -0.04 & -0.04 & -0.11 & -0.24 \\
\hline Vietnam & -1.16 & -0.20 & -1.04 & -1.50 \\
\hline \multicolumn{5}{|c|}{ Change rate in product output } \\
\hline Indonesia & 0.14 & 0.17 & 0.02 & 0.54 \\
\hline Vietnam & 2.66 & 0.93 & 1.42 & 8.10 \\
\hline \multicolumn{5}{|c|}{ Change rate in exports } \\
\hline Indonesia & 0.23 & 0.27 & 0.58 & 1.33 \\
\hline Vietnam & 6.50 & 1.27 & 4.99 & 8.34 \\
\hline
\end{tabular}

Note: Indonesia's change rates are results for the $02 E$-idn scenario and Vietnam's change rates are for the $03 E$-vnm scenario.

Source: The authors' compilation based on the GTAP 10A Data Base.

\subsubsection{The 11E-chnivit scenario: total effects}

The result of the $11 E$-chnivit scenario is the sum of the results of the 01 -chn scenario and the $10 \mathrm{E}$-ivit scenario, and the result of the $10 \mathrm{E}$-ivit scenario is the sum of the results of the $02 E$-idn to $05 E$-trk scenarios.

Under the 10E-ivit scenario, GDP appears to increase in the host countries and remain almost unchanged in other countries. China and Mongolia are affected negatively in the $01 E$-chn scenario, which is reflected in their GDP under the 11E-chnivit scenario. Electricity capital movements from China have a negative impact on China's GDP and a positive impact on the recipient country. Mongolia seems to experience relatively strong effects due to their background of coal and electricity trade with China.

The result of $11 E$-chnivit scenario can be considered the sum of the four bilateral scenarios from $06 E$-chnidn to 09E-chntrk. In the bilateral FDI scenarios, the rate of decrease in China's electricity capital is smaller than in the $11 E$-chnivit scenario. China's GDP tends to decline by $0.01 \%$ only in the $06 E$-chnidn and 07E-chnvnm scenarios in which the shock value on China's power capital is relatively large. A clearly negative effect on Mongolia's GDP is only observed in terms of its FDI against Vietnam.

\subsection{Impact on welfare}

We now measure welfare changes due to FDI using equivalent variation (EV). EV measures welfare change in terms of income change, assuming that the initial price system remains constant. For example, increased production factors, 
more efficient resource allocation, and technological progress will enhance economic welfare. Improving the terms of trade also increases economic welfare, as one unit of exports will enable the consumption of more imports.

Table 6.10 displays the EV caused by a change in electricity capital. In the $01 E$-chn scenario (i.e., capital decreases), there are negative EV values not only in China but also in other countries. The EV is positive in the capitalrecipient country for the $02 E$-idn to $05 E$-trk scenarios. In any given scenario, changes in economic welfare occur even in countries wherein the amount of capital does not change. Some countries or regions have a positive effect, whereas others have a negative effect. Although the effect on the EV in countries in which the electricity capital is unchanged is extremely marginal, it nonetheless suggests that there are various channels of FDI influence at work.

To understand the effect on EV, we analyzed the term's components. In the GTAP-E model, EV can be decomposed into seven components: resource allocation effects, element endowment effects, technological change effects, population effects, terms-of-trade effects, investment goods price effects, and emissions trading effects. ${ }^{9}$ The specific components related to this analysis include the resource allocation, element endowment, and terms-oftrade effects. Resource allocation and factor endowment effects are important in the countries in which the capital stock changes. The terms-of-trade effect is caused mainly by changes in electricity and coal prices.

\subsubsection{The 01E-chn scenario}

In the 01E-chn scenario, the Chinese EV consists mainly of the resource allocation effect (-US\$ 669.9 million), the element endowment effect (-US\$1,058.6 million), and the terms-of-trade effect (US\$264.7 million). The rise in the price of electricity causes the prices of Chinese exports to rise, improving the terms of trade in China while worsening them in other countries. The degree of the effect of such deterioration depends on the volume of trade with China. China's export value is US\$ 2,499.7 billion; its shares in the exports of EUEFTA, the USA, and Japan are $21.47 \%, 19.01 \%$, and $8.02 \%$, respectively. Therefore, the reduction in the $\mathrm{EV}$ of these countries or regions is relatively large.

Furthermore, there is a decrease in demand for imported intermediate inputs from China's electrical power industry because of a decrease in its production. This worsens the terms of trade for exporting regions by decreasing their prices. For example, Oceania's EV is -US\$ 51.2 million, of which the terms-of-trade effect is -US\$ 41.5 million. Of the -US\$ 41.5 million, -US\$ 13.9 million is caused by mining prices and -US\$ 9.1 million by coal prices. The same phenomenon can be observed in Indonesia and Mongolia.

\subsubsection{The 02E-idn, 03E-vnm, 04E-ind, and 05E-trk scenarios}

The contribution of the element endowment effect dominates the positive EV of the capital host country in the 02E-idn through 05-E-trk scenarios. However, the terms-of-trade effect of the host country is negative. In the 


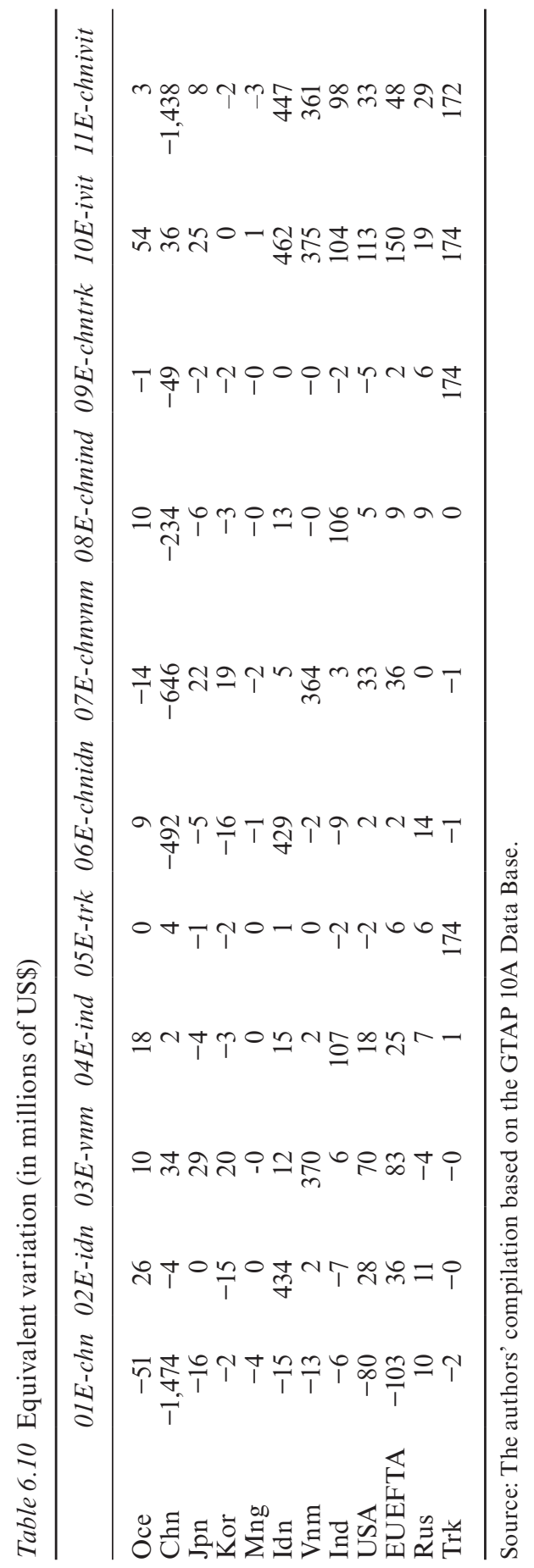


applicable scenarios, the element endowment effects of Indonesia, Vietnam, India, and Turkestan are US\$ 507.2 million, US\$ 430.4 million, US\$ 241.5 million, and US\$ 136.8 million, respectively, and the terms-of-trade effects are -US\$20.2 million, -US\$ 221.2 million, -US\$ 76.5 million, and -US\$ 9.1 million, respectively. Worsening terms of trade result because lower electricity prices lead to lower export prices.

Countries importing at lower prices from the host country, however, will experience positive terms-of-trade effects. This is especially noticeable in the $03 E$-vnm scenario. Owing to the increase in electricity capital, the product prices of most industries in Vietnam will decrease. Vietnam's export value is US\$ 166.2 billion, and its share of exports to EUEFTA, the USA, China, and Japan is as high as $19.74 \%, 18.57 \%, 14.30 \%$, and $9.69 \%$, respectively. A relatively large increase in EV can be seen in these countries and regions.

Lower export prices in host countries negatively impact the terms of trade of the countries that export them. This is particularly remarkable for South Korea's petroleum and coal products in the $02 E$-idn scenario. South Korea's EV is -US\$ 15.1 million, of which -US\$ 15.0 million is attributable to the deterioration in the terms of trade. Of this deterioration, the portion due to the rise in coal import prices is -US\$ 4.2 million, followed by the portion due to the decline in the export prices of petroleum and coal products, which is -US\$ 3.8 million. South Korea's petroleum and coal exports to Indonesia are as high as US\$ 36.4 billion, accounting for $14.71 \%$ of its total petroleum and coal exports. Conversely, the share of petroleum and coal exports to Indonesia is low at $1.61 \%$ and $1.12 \%$ in China and Japan, respectively. Therefore, the terms-oftrade effect of petroleum and coal products in both countries is rather positive.

Increased power generation in the recipient regions also affects the terms of trade. An increase in coal demand due to an increase in power generation in the host countries has a negative impact on the terms of trade of the coal-importing country and a positive impact on the terms of trade of the exporting country. Under the four scenarios, Oceania, Mongolia, and Indonesia experience a positive terms-of-trade effect for coal, while China, South Korea, Japan, and India have a negative effect.

\subsubsection{The 11E-chnivit scenario: total effects}

Under the 10E_ivit scenario, the EV of most countries is positive, and an increase in Vietnam's electricity capital contributes to positive EV other than that of the host country. However, in the $11 E_{-}$chnivit scenario, the EV in most countries decreases owing to the negative impact of China's decrease in electricity capital. From the perspective of bilateral capital movements, the negative impact of capital movements to Vietnam on China's EVs is the greatest.

\subsection{Impact on $\mathrm{CO}_{2}$ emissions}

Tables 6.11 and 6.12 summarize the impact of $\mathrm{CO}_{2}$ emissions. In this subsection, we focus on China. 


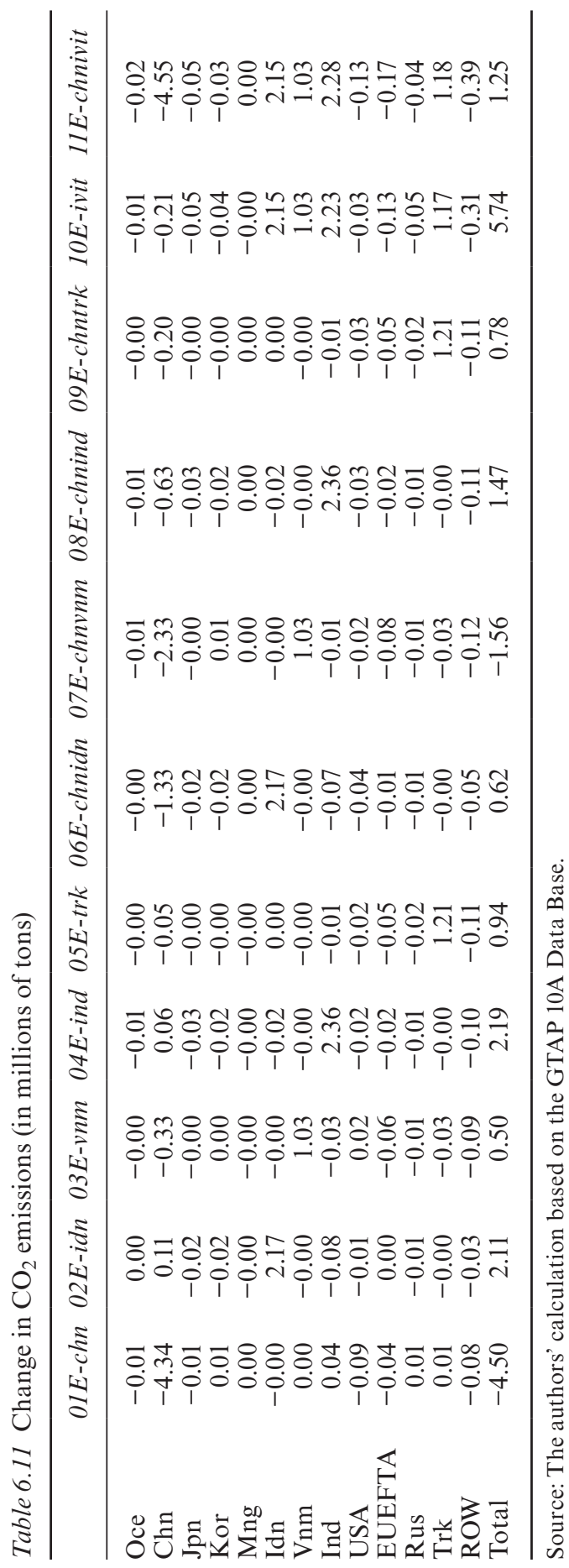




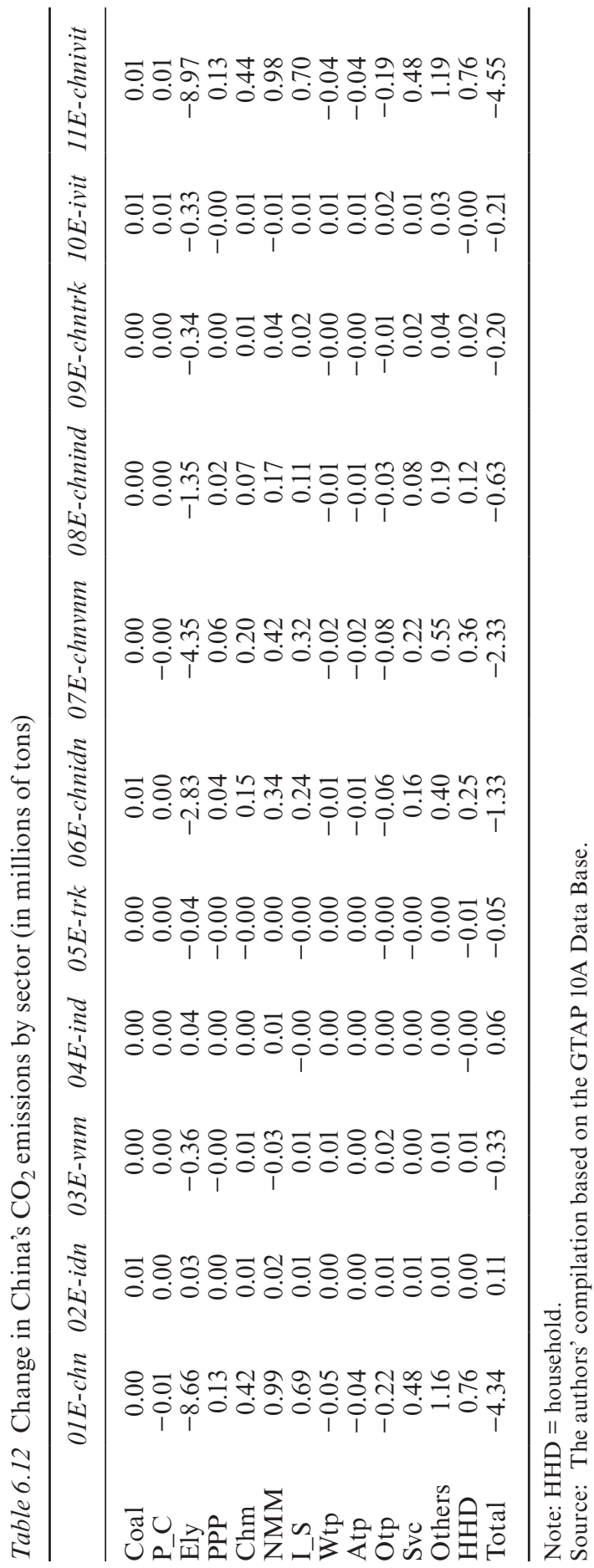




\subsubsection{The 01E-chn scenario}

In the $01 E$-chn scenario, a $1.91 \%$ reduction in capital stock in China's power sector will reduce China's $\mathrm{CO}_{2}$ emissions by approximately 4.34 million tons. $\mathrm{CO}_{2}$ emissions in the power sector will decrease by 8.66 million tons, whereas emissions will increase in many other sectors. This is especially true in non-metallic mineral products, iron and steel, chemical products, and services-all sectors that have high $\mathrm{CO}_{2}$ emissions. Household $\mathrm{CO}_{2}$ emissions will also increase by 0.76 million tons. In this scenario, capital rental costs in China's power sector will increase by $3.62 \%$, thereby increasing electricity prices by $0.82 \%$. Conversely, the price of coal will decline by $0.02 \%$, prompting the replacement of electricity with coal, consequently increasing $\mathrm{CO}_{2}$ emissions in many sectors other than electricity.

\subsubsection{The 02E-idn, 03E-vnm, 04E-ind, and 05E-trk scenarios}

The increase in electricity capital stock in Vietnam and Turkestan reduces $\mathrm{CO}_{2}$ emissions in China, whereas the increase in electricity capital stock in Indonesia and India increases $\mathrm{CO}_{2}$ emissions in China.

In the $03 E$-vnm and $05 E$-trk scenarios, electricity trade helps reduce $\mathrm{CO}_{2}$ emissions from China's electricity sector. Under the $03 E$-vnm and $05 E$-trk scenarios, Vietnam and Turkestan increase their power exports to China by $113.59 \%$ and $8.24 \%$, respectively. In the $03 E$ - $v n m$ scenario, the $\mathrm{CO}_{2}$ emissions from China's power reduction are relatively large at approximately 0.36 million tons. Moreover, in these scenarios, China's $\mathrm{CO}_{2}$ emissions are also reduced in some energy-intensive industries in addition to reductions in the electrical power sector.

In the $02 E$-idn and $04 E$-ind scenarios, output is virtually unchanged in China's electricity sector, but its $\mathrm{CO}_{2}$ emissions increase. ${ }^{10}$ Furthermore, in the $02 E$-idn scenario, an increase in $\mathrm{CO}_{2}$ emissions from coal, chemical products, iron and steel, and non-metallic mineral products can also be observed in China.

\subsubsection{The 11E-chnivit scenario: total effects}

The decrease in $\mathrm{CO}_{2}$ emissions in China is greater in the $11 E$-chnivit scenario than in the $01 E$-chn scenario because of the reduction in $\mathrm{CO}_{2}$ emissions in China precipitated by the increase in capital in Vietnam and Turkestan. Most of China's $\mathrm{CO}_{2}$ emissions reductions in the $11 \mathrm{E}$-chnivit scenario are attributable to the electricity sector. Further, $\mathrm{CO}_{2}$ emissions from China's most energy-intensive industries are increasing. This is because of a decrease in Chinese capital rather than an increase in the host country's capital.

In the 07E-chnvnm bilateral capital movement scenario, the decrease in $\mathrm{CO}_{2}$ emissions in China exceeds the increase in $\mathrm{CO}_{2}$ emissions in Vietnam, thereby reducing overall global $\mathrm{CO}_{2}$ emissions. However, under the other 
bilateral scenarios, the opposite is true. Global $\mathrm{CO}_{2}$ emissions increase in the $11 E$-chnivit scenario because the effect of the latter outweighs that of the former.

\section{Discussion}

In this section, we discuss the effects of China transferring their power sector to other Asian countries/regions in the context of carbon relocation using the results of scenarios such as the $06 E_{-}$chnidn, 07E_chvnm, 08E_chnind, $09 E_{-}$chntrk, and $11 E_{-}$chnivit scenarios in which electricity capital declines in China and increases in the host country.

Figure 6.2 illustrates the change in $\mathrm{CO}_{2}$ emissions for each scenario according to China's power and nonpower sectors including households, the host countries' power and nonpower sectors including households, and the rest of the world (ROW). The decrease in $\mathrm{CO}_{2}$ emissions is attributable to China's power sector, the host countries' nonpower sector, and the ROW. Conversely, the increase in $\mathrm{CO}_{2}$ emissions is due to China's nonpower sector and the power sector of the host countries. Rising electricity prices in China cause a shift from electricity to coal in the nonpower sector's energy mix, resulting in an increase in $\mathrm{CO}_{2}$ emissions from the nonpower sector despite its stagnant production. The opposite occurs in the host country. ${ }^{11}$ One of the reasons for the decrease in $\mathrm{CO}_{2}$ emissions in the ROW is the declining production of energy-intensive goods due to international competition with the host country. If the production base is moved to the host country from

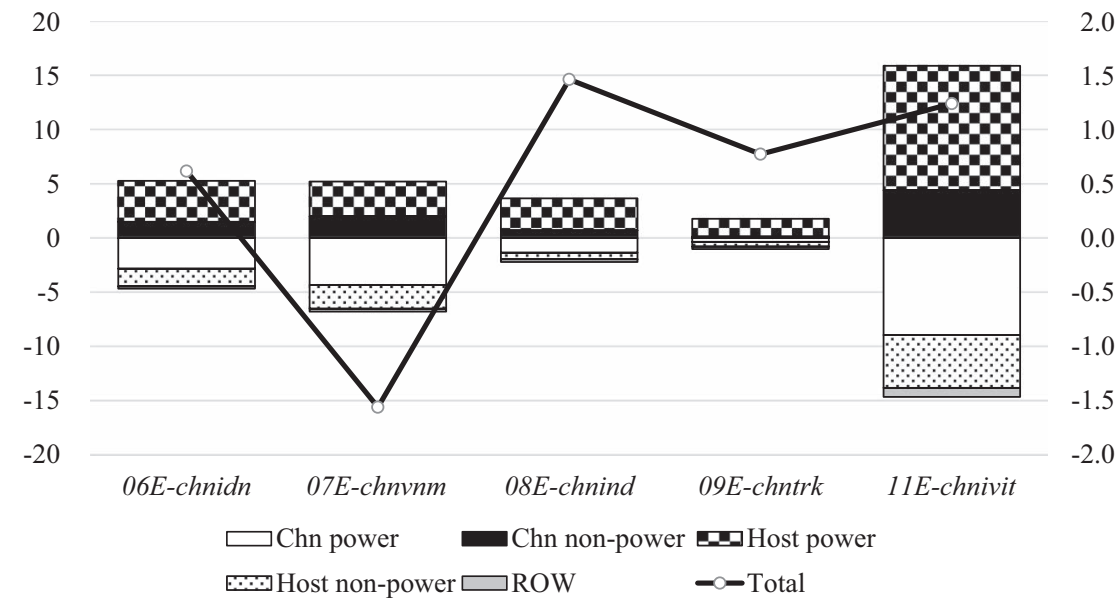

Figure 6.2 Change in $\mathrm{CO}_{2}$ emissions caused by China's OFDI (in millions of tons). Note: The left-hand vertical axis is for the bar graph and the right-hand vertical axis corresponds to the line graph.

Source: The authors' compilation based on data from the GTAP 10A Data Base. 
a country with relatively lower $\mathrm{CO}_{2}$ emissions per unit of production, it will cause an overall increase in global $\mathrm{CO}_{2}$ emissions.

Only in the 07E-chnvnm scenario do global $\mathrm{CO}_{2}$ emissions decrease. The first reason is that the decrease in $\mathrm{CO}_{2}$ emissions in China's power sector is greater than the increase in Vietnam's power sector. Electricity imports from Vietnam are one of the causes underlying declining electricity production in China.

The second reason is that the decrease in the $\mathrm{CO}_{2}$ emissions of Vietnam's nonpower sector is relatively large. As seen in the section on the impact on power sector, the low capital-labor ratio of Vietnam's electricity sector prompts a significant drop in electricity prices. This causes a shift from coal to electricity in the energy mix of nonpower sectors in the context of Vietnam's high share of electricity costs. In other words, the degree of decline in electricity prices and the progress of electrification in the nonpower sector mitigate carbon leakage. ${ }^{12}$

Figure 6.2 shows that the increase in $\mathrm{CO}_{2}$ emissions in India's power sector seems to be large considering the increase in its capital. The increase in the power sector capital in India is $48 \%$ of those in Indonesia, while the increase in $\mathrm{CO}_{2}$ emissions in the power sector in India is as much as $78 \%$ of those in Indonesia. Possible reason for the relatively larger increase in $\mathrm{CO}_{2}$ emissions is low efficiency of coal power generation in India. According to the GTAP Data Base, coal energy consumption per billion US\$ of electricity capital is 9.90 Mtoe in China, 14.61 Mtoe in Indonesia, 3.05 Mtoe in Vietnam, 18.58 Mtoe in India, and 4.74 in Turkestan. Differences in power generation technology and quality of coal between China and host countries, which is indicated in Chapter 2, may account for carbon leakage.

In the $11 E$-chnivit scenario, the increase in $\mathrm{CO}_{2}$ emissions in the host country's power sector outweighs the decrease in China's electricity sector. Although the decrease in $\mathrm{CO}_{2}$ emissions from the host country's nonpower sector outweighs the increase in China's nonpower sector, it is not sufficiently large to offset the net increase in $\mathrm{CO}_{2}$ emissions in the power sector. This results in an increase in Global $\mathrm{CO}_{2}$ emissions. The carbon leakage rate is $127.4 \%$ when calculated as the ratio of the change in $\mathrm{CO}_{2}$ emissions in countries/regions other than China to the amount of $\mathrm{CO}_{2}$ reduction in China. ${ }^{13}$ In other words, it can be said that since 2014, China's OFDI in coal power generation has taken on the appearance of carbon relocation greater than $100 \%$.

As far as we know, few previous studies have analyzed the environmental effects of FDI using a CGE model. Fujikawa and Ban (2016) treated capital as a mobile factor, while this method could not examine the impact of capital transfer in any particular sector. The CGE model with industry-specific capital used in this chapter makes it possible to establish the effect of FDI in the electricity sector and clarifies the factors for carbon relocation.

Some of the problems encountered in this study and potential future issues are worth noting. First, the productivity of capital (i.e., power generation 
efficiency, in this study) and the energy mix of electricity generation depend not on the investing country but the recipient country due to the nature of the GTAP-E model. Therefore, it is necessary to distinguish between domestically and foreign-capitalized power plants. ${ }^{14}$

Second, the GTAP-E model used herein does not differentiate between various power generation methods. ${ }^{15}$ The capital transfer of coal-fired power generation is assumed; however, for a strict analysis, a model that distinguishes between power generation methods is required.

Furthermore, there are various technologies in coal-fired power generation. It is also necessary to consider the difference in coal-fired power generation technology when estimation the nominal amount of OFDI in China. These are the future challenges for further investigations into this topic.

\section{Conclusion}

This chapter analyzed the economic and environmental (i.e., $\mathrm{CO}_{2}$ ) effects of capital movements of China's electricity sector to Indonesia, Vietnam, India, and Turkestan using the GTAP-E model and China's Global Power Database constructed by Boston University.

We found that the transfer of electricity capital affected not only electricity production and $\mathrm{CO}_{2}$ emissions in China and the host country but also production by other industries and the economies and environments of other countries/regions. The main conclusions are as follows:

- The overseas movement of Chinese electricity capital reduces China's GDP, and the resultant decline in China's coal demand negatively impacts coal production in coal-exporting countries. The degree of GDP increase in the host country depends on the capital-labor ratio and share of electricity costs as well as the magnitude of the capital increase.

- China's OFDI affects EVs through the terms-of-trade effect in countries and regions other than China and capital-receiving countries. The terms-of-trade effect depends on whether the country is an energy exporter or importer and its trade structure with China and capitalreceiving countries.

- The reduction in $\mathrm{CO}_{2}$ emissions in China's electricity sector is undermined by the shift in demand for coal in the nonpower sectors but is strengthened by electricity imports. The increase in $\mathrm{CO}_{2}$ emissions from the electricity sector in the host country is mitigated by the shift in demand for electricity in the nonpower sectors.

- With the exception of OFDI to Vietnam, the OFDI of China's power sector increases global $\mathrm{CO}_{2}$ emissions.

This chapter demonstrates that overseas capital movements from the Chinese power sector increase overall global $\mathrm{CO}_{2}$ emissions, although the parameters used in this model are not necessarily generalized. If China makes 
direct investments to reduce domestic emissions (i.e., for domestic optimization), such a decision could ultimately prove globally counterproductive. This result indicates that international society must be cautious about the countries and regions chosen for allocations of capital investment.

\section{Acknowledgments}

The authors are grateful to Professor Shiro Takeda at Kyoto Sangyo University for the useful comments that he provided at the 25th Annual Conference of the Society for Environmental Economics and Policy Studies. This work was supported by Japan Society for the Promotion of Science, Grants-in-Aid for Scientific Research, under Grant Numbers JP18H03426, JP19K12459, and JP20K12291, and Applied Social System Institute of Asia, Nagoya University.

\section{Notes}

1 See Institute for International Trade and Investment (2020) for more information on FDI statistics.

2 See Gallagher et al. (2019). The data includes China's developmental financing of overseas power generation.

3 See Tsutsumi and Kiyota (2002) and Lejour and Romagosa (2006) for surveys of CGE models applied to FDI analysis.

4 See Burniaux and Truong (2002) and McDougal and Golub (2007) for additional details on the GTAP-E model; see Hertel (1997) and Corong et al. (2017) for more information on the GTAP model.

5 A constant elasticity of transformation specification is used in the GTAP model. The change rate of the supply of sluggish factor $i$ for use in industry $j$ in country $r q^{2} s_{i, j, r}$ is expressed as follows: $q e s_{i, j, r}=q e_{i, r}-\operatorname{ETRE}_{i, r}\left(p e s_{i, j, r}-p e_{i, r}\right) \cdot q e_{i, r}$, $p e s_{i, j, r}$, and $p e_{i, r}$ denote the change rates in the aggregate supply of a sluggish factor, industry-specific returns to the sluggish factor, and aggregate returns to the sluggish factor, respectively. ETRE $_{i, r}$ represents the transformational elasticity and is negative.

6 The Armington assumption states that products are differentiated according to their countries of origin. See Armington (1969).

7 Overnight costs include direct/indirect construction costs, the owners' costs, and so on. See IEA/NEA (2015, p. 31) for the definition of overnight costs.

8 China's importing-country share of coal is as follows: Oceania, 40.80\%; Indonesia, 30.22\%; and Mongolia, 5.29\%.

9 See Huff and Hertel (2000) for additional details about decomposing welfare changes into the GTAP model.

10 The CES specification in the power sector does not have additive property which assures that the sum of inputs (measured Mtoe) sums to the total output (also in Mtoe). When the substitution between domestic energy and imported energy occurs, simulation results can differ from intuition. In the $02 E$-idn and $04 E$-ind scenarios, imported coal in China's power sector will be replaced by domestic coal due to the rise in imported coal price. See Peters (2016) for additive property.

11 Since the model assumes that the production function is as shown in Figure 6.1, substitution between electricity and coal in the energy mix could possibly occur.

12 We should note that the power sector is aggregated regardless of power source in the GTAP-E model. While thermal power generation is mainstream in China, the 
ratio of hydroelectric power generation is relatively high in Vietnam. Therefore, when simulating an increase in Vietnam's power capital, the increase in $\mathrm{CO}_{2}$ emissions is suppressed. This is a limitation of utilizing the GTAP-E model for such an analysis.

13 The carbon leakage rate is defined as follows:

$$
\text { carbon leakage rate }=\frac{\sum_{r} \text { Change in } \mathrm{CO}_{2} \text { emissions in } r}{\text { Reduction in } \mathrm{CO}_{2} \text { emissions in China }} \times 100
$$

$r=$ Indonesia, Vietnam, India, Turkestan, and the ROW.

Each country/region's contribution is calculated as follows:

$$
\text { contribution }=\frac{\text { Change in } \mathrm{CO}_{2} \text { emissions in } r}{\text { Reduction in } \mathrm{CO}_{2} \text { emissions in China }} \times 100
$$

The contributions of Indonesia, Vietnam, India, Turkestan, and the ROW are $47.2 \%, 22.6 \%, 50.1 \%, 25.9 \%$, and $-18.4 \%$, respectively.

14 With the recent development of FDI stock data and foreign affiliate sales data, it has now possible to analyze FDI using a GTAP-based FDI model that distinguishes between domestically and foreign-owned companies (Fukui and Lakatos, 2012; Lakatos and Fukui, 2014; Tsigas and Yuan, 2017). Applying such a model to an analysis of FDI's environmental impact is necessary.

15 The GTAP-E-Power model, which is an extension of the GTAP-E model, includes different generating technologies. See Peters (2016) includes different generating technologies.

\section{References}

Armington, P. S. (1969) A Theory of Demand for Products Distinguished by Place of Production, International Monetary Fund Staff Papers, XVI, 159-178.

Ban, K., Ohtsubo, S., Kawasaki, K., Ono, M., Matsuya, M., Tsutsumi, M., Kitaki, H. and Ono, H. (1998) Applied General Equilibrium Analyses of Current Global Issues: APEC, Foreign Direct Investment, New Regionalism, and Environment, Economic Analysis, 156, the Economic and Social Research Institute. Retrieved June 10, 2020 from http://www.esri.go.jp/jp/archive/bun/bun156/bun156b.pdf (in Japanese).

Brown, D. K., Deardorff, A. V. and Stern, R. M. (1992) A North American Free Trade Agreement: Analytical Issues and a Computational Assessment, The World Economy, 15(1), 11-30.

Burniaux, J. M. and Truong T. P. (2002) GTAP-E: An Energy-Environmental Version of the GTAP Model. GTAP Technical Paper, 16. Retrieved June 10, 2020 from https://www.gtap.agecon.purdue.edu/resources/download/1203.pdf

Corong, E. R., Hertel, T. W., McDougall, R. A., Tsigas, M E. and Mensbrugghe, D. (2017) The Standard GTAP Model, Version7, Journal of Global Economic Analysis, 2(1), 1-119. http://dx.doi.org/10.21642/JGEA.020101AF

Fujikawa, K. and Ban, H. (2016) Globalization of the Economy and Load on the Global Environment in Otsubo, S. (ed.) Globalization and Development, Volume 1, Oxon: Routledge, 200-227.

Fukui, T. and Lakatos, C. (2012) A Global Database of Foreign Affiliate Sales, GTAP Research Memorandum, 24. Retrieved October 16, 2020 from https://www. gtap.agecon.purdue.edu/resources/download/6082.pdf 
Hertel, T. W. (ed.) (1997) Global Trade Analysis: Modeling and Applications, Cambridge: Cambridge University Press.

Huff, K. M. and Hertel, T. W. (2000) Decomposing Welfare Changes in the GTAP Model, GTAP Technical Paper, 5. Retrieved March 7, 2020 from https://www. gtap.agecon.purdue.edu/resources/download/2365.pdf

Institute for International Trade and Investment (2020) Collection of Direct Investment Statistics of Major Countries in the World, I, Overview (in Japanese).

International Energy Agency (IEA)/Nuclear Energy Agency (NEA) (2015) Projected Costs of Generating Electricity, 2015 Edition, Paris: OECD Publishing. https://doi. org/10.1787/cost_electricity-2015-en

Lakatos, C. and Fukui, T. (2014) The Liberalization of Retail Services in India, World Development, 59(C), 327-340. https://doi.org/10.1016/j.worlddev.2014.01.013

Lejour, A. and Romagosa, H. R. (2006) Foreign Direct Investment in Applied General Equilibrium Models: Overview of the Literature, CPB Memorandum, CPB Netherlands Bureau for Economic Policy Analysis, 169. Retrieved October 16, 2020 from https://www.cpb.nl/sites/default/files/publicaties/download/memo1690.pdf

Li, Z., Gallagher, K. P. and Mauzerall, D. L. (2020) China's Global Power: Estimating Chinese Foreign Direct Investment in the Electric Power Sector, Energy Policy, 136. https://doi.org/10.1016/j.enpol.2019.111056

McDougall, R. and Golub, A. (2007) GTAP-E: Revised Energy-Environmental Version of the GTAP Model. GTAP Research Memorandum, 15. Retrieved February 18, 2020 from https://www.gtap.agecon.purdue.edu/resources/download/4212.pdf

Peters, J. (2016) GTAP-E-Power: An Electricity-Detailed Economy-Wide Model, Journal of Global Economic Analysis, 1(2), 156-187. http://dx.doi.org/10.21642/ JGEA.010204AF

Tsigas, M. and Yuan, W. (2017) Addressing Excess Capacity-The Effect of China's FDI in the Iron and Steel Industry in Five Central Asian States: A GTAP-FDI Model Perspective, Conference Paper presented at the 20th Annual Conference on Global Economic Analysis. Retrieved October 16, 2020 from https://www. gtap.agecon.purdue.edu/resources/download/8644.pdf

Tsutsumi, M. and Kiyota, K. (2002) Impacts of Japan's Free Trade Agreement: Analysis by CGE Model, JCER Discussion Paper, 74. Retrieved October 16, 2020 from http://www.jcer.or.jp/report/discussion/detail3055.html (in Japanese).

\section{Database}

Aguiar, A., Chepeliev, M., Corong, E., McDougall, R. and van der Mensbrugghe, D. (2019) The GTAP Data Base: Version 10, Journal of Global Economic Analysis, 4(1), 1-27. http://dx.doi.org/10.21642/JGEA.040101AF

Gallagher, K. P., Li, Z., Chen, X. and Ma, X. (2019) China's Global Power Database, Global Development Policy Center, Boston University. Retrieved December 25, 2020 from https://www.bu.edu/cgp/ 